\title{
Research on the Status of European and Chinese Trade Competition in the Third Party Market
}

\author{
Ding Shiying ${ }^{1}$, Hou Xiaocong ${ }^{1}$, Mu Pengyu ${ }^{2}$ \\ ${ }^{1}$ School of Economics and Management, North University of China, Taiyuan, Shanxi, 030051 \\ ${ }^{2}$ University of International Business and Economics, Beijing, 100029
}

\begin{abstract}
China's increasingly important role in the global economy has changed the nature of global competition and reshaped international trade. At the same time, the EU has long been the most important force in global trade and continues to maintain a very large trade surplus. We discussed whether China is an increasingly important competitor of Europe in third-party markets, especially Latin America. More specifically, we have empirically estimated the elasticity of substitution between European exports and Chinese exports to Latin American economies (i.e. Their response to Latin American exports to changes in relative export prices). The results of this article show that over time, the competition between China and the EU in Latin America has increased. Before 2007, the competition between China and the EU was relatively high. Less, this reflects to a certain extent the fact that China mainly exports inferior products. However, since 2007, the substitution elasticity has increased, reflecting China 's rise in the value chain upstream. We also studied China and the EU's. The competition between the key industries of the EU exported by the Americas. We found that the competition between China and Europe in the field of motors and road vehicles is more intense. This should be sought Global level to maintain the competitiveness of European sounded the alarm.
\end{abstract}

\section{INTRODUCTION}

China is one of the fastest growing economies in the past few decades. China has experienced continuous capital accumulation and major adjustments in the output sector structure [1]. At the same time, trade liberalization has reduced trade costs and enabled China to better integrate into the global economy [2]. How China's manufacturing production and exports adapt to trade liberalization and capital deepening [3]. This article attempts to answer this question. We have recorded new facts about Chinese manufacturing companies and developed a cross-industry comparative advantage and intra-industry heterogeneity trade model [4].

In recent years, China has emerged as a dominant economic power, changing the nature of global competition and reshaping international trade [5]. China's increased competitiveness has had a major impact on the exports of developing and developed countries. China's growing export quotas have raised concerns in other export economies such as the European Union [6]. However, the reality that is often overlooked is that China not only competes with developed countries in the domestic market, but also in third-party markets [7]. China is competing in the third-party market globally. The increasingly important role played by this can be seen in the XTC1 targeting 68 economies [8]. In view of this, to what extent the country is competing with developed countries in developing countries has become a question worthy of study [9].

We are concerned about the competition between China and Europe in Latin America. This is a good case study because Europe has long been a major exporter to Latin America, and China's market share increased rapidly from $3 \%$ in 2000 to 2016 . It was $18.3 \%$ of the year and has become the largest exporter to several Latin American countries [10].

Some studies have already analyzed this issue. Nowak reviewed the trade and financial relations between China and the EU and Latin America from 2000 to 2013, and found that after the global financial crisis, Europe's willingness to strengthen relations with Asian countries made its trade relations with Latin America Deterioration. At the same time, China has become a major exporter in Latin America. Roderick and Hausman and others have shown that Chinese exports tend to be sophisticated and highly productive, similar to the export structure of high-income countries. However, consider to the vertical connection to modern global production, research using the concept of trade value added has downplayed the competitive effect. Similarly, Hallak and Schott showed that the potential quality of China 's exports and high-income economies are different. In analyzing China 's competition against Europe versus Asia, Mandelson and Ferrero-Waldner also agreed with this view when it came to the impact of exports from emerging markets such as Africa and Latin America. In 
contrast, Poncet showed a more encouraging result for Europe and found that although the EU and China have Similarities, but the European Union is well under pressure from China's competition.

Although the conclusion is interesting, few of these papers formally estimate the export substitution elasticity of country a (China in our case) and another country (EU in our case). Our paper estimates empirically the substitution elasticity of exports from third-party markets (that is, Latin America) fills the gap. In particular, we have designated a super by assuming that Latin America can import from various sources and allowing this substitution elasticity to vary in different trading pairs. Logarithmic demand function. In addition to general estimates, we also estimate this sector-level elasticity of key industries exported by China and the EU to Latin America.

Our estimates of the export demand function confirm that the competition between China and the EU has been evolving over time. Although the EU and China seem to have increased trade complementarity before 2007, competition has become more intense since then. It reflects that China's export content has been moving upstream in the value chain, providing more high-quality products, and competing with EU products. Moreover, China and the EU are particularly competitive in some high-value-added products, such as motors. The discovery should sound the alarm bell for Europe in order to maintain its competitiveness at the global level.

We first use enterprise-level data to compare the production and export situation of China's manufacturing industry in 1999 and 2007. On the basis of Schott (2003), we define the industry as "Ho aggregate", and according to the company's capital share will Enterprise reorganization into 100 industries. Comparing the 2007 data with the 1999 data, the distribution of enterprises and production industries is shifted to capital-intensive industries. However, in each industry, the distribution of exporters is shifting to labor-intensive industries. In addition, in an industry, the export proportion of labor-intensive enterprises increases, and the export proportion of capital-intensive enterprises decreases; the export of labor-intensive industry enterprises accounts for a large proportion of total output, and the export of capital-intensive industries accounts for the proportion of total output smaller. Using this framework, we numerically solved the model and used the method of moments to estimate the structure of the two-year model parameters. The results show that the capital-labor ratio more than doubled between 1999 and 2007, and technological progress. Obviously, it is conducive to labor-intensive industries, and trade liberalization mainly comes from the reduction of fixed export costs.

However, there are two points to note. First, we use total trade data instead of value-added data. Although Latin America is relatively isolated from the global production chain (Mexico is an obvious exception), the use of total trade data may still be distorted to some extent our results. Second, our methodology does not provide a clear specification of the supply function, but we try to control changes in supply by introducing time dummies as agents of total supply shocks. Finally, we use Latin America and the EU as regional groups. Processing. Some results are provided for the largest EU country, but the level of detail is different from the entire EU.

\section{INSTITUTIONAL BACKGROUND AND FACTUAL SITUATION ANALYSIS}

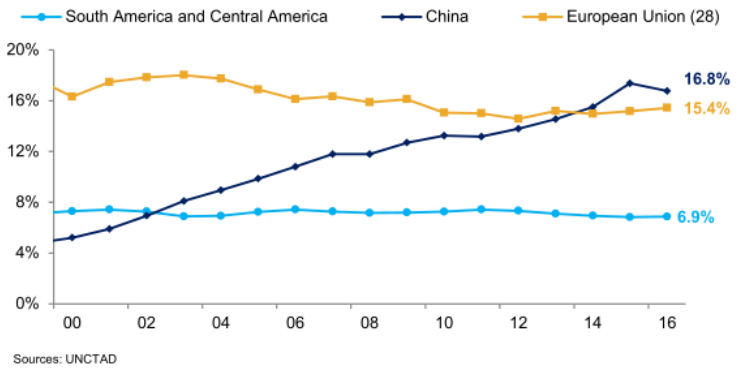

Figure1 World export share

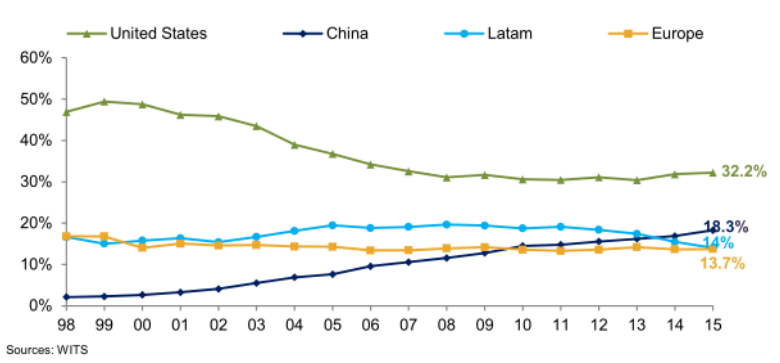

Figure2 Latin American import share, 1998-2015

China and the EU are the two largest trading giants in the world (Figure1), and their competition in Latin America is increasingly fierce. Europe has been an important player in Latin America, and its market share has stabilized at around $14 \%$ in the past 15 years However, in 2000, China accounted for only 3\% of Latin American imports from the world outside Latin America, but this market share rapidly increased to $18.3 \%$ in 2016 (Figure2). In addition, the EU and China both have huge trade surpluses with Latin America : China has always maintained a lasting trade surplus, reaching a record 90 billion U.S. dollars in 2015 (Figure3), while Europe reversed its trade deficit with Latin America after 2012, and the surplus reached a peak of 16 billion U.S. dollars in 2016 (Figure4).

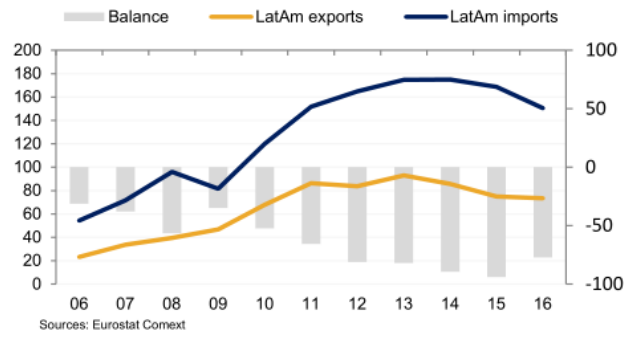

Figure3 Latin America trade relations with China, in billions of dollars 


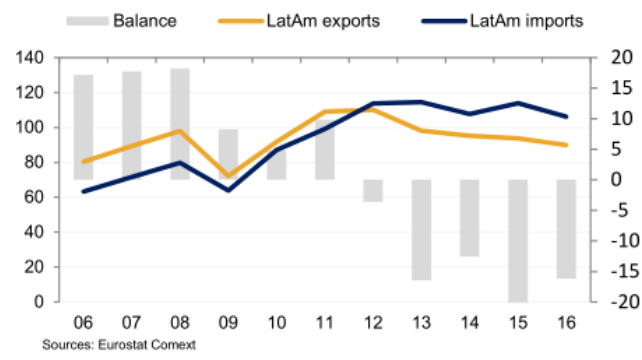

Figure4 Trade relations between Latin America and Europe, in billions of dollars

In this context, one cannot help asking whether China's rise has gradually replaced the EU's exports to Latin America. In order to better understand the competition between China and Europe in Latin America, we have examined the product-level import structure of Latin America relative to the EU and China. This shows that the biggest competition between the two groups in Latin America is in the categories of general machinery, road vehicles and electric machinery. The latter stands out because it is the second largest export sector from the EU to Latin America, from China to the fifth largest export sector in Latin America. In addition, the two groups are competing in the supply of road vehicles, which is the third largest export industry in Europe and the eighth largest export industry in China. In other areas, China is in office machinery, telecommunications equipment and some labor-intensive products (such as textile yarn and clothing) have special comparative advantages, and the European Union is in a leading position in medicine and pharmaceutical products, power generation machinery, and petroleum and chemical products.

Among Latin American countries, Brazil, Mexico and Chile are China's three largest trading partners. In 2016, China's trade deficits with Brazil and Chile were approximately US \$24 billion and US \$ 6 billion, respectively, mainly because China mainly imported oil from Brazil Seeds and oily fruits, copper is imported from Chile. However, due to China's motor exports, China's trade surplus with Mexico is as high as 22 billion US dollars. The EU also exports a lot to the three major Latin American countries. Due to the EU 's comparative advantage in exporting cars, the EU There is a surplus for Mexico.

Our specialization indicators show that the EU and China tend to export more similar products to Latin America. That is to say, the CI/CC method only shows the potential competition space (product coverage) for EU and China exports to Latin America, this does not necessarily reflect the exact competitive position between them. For example, both the EU and China export cars and their parts to Latin American countries, but European cars and parts should generally have higher quality standards than China. Therefore, even China The company is expanding their market in Latin America, they may target consumers with different goals than the
EU, and competition may not be as intense as it seems. To solve this problem, we need to consider the impact of price adjustments in order to measure more accurately Alternative elasticity. This requires more rigorous quantitative analysis.

\section{A CASE STUDY OF EXPORT COMPETITION IN THE THIRD-PARTY MARKET}

To assess the degree of competition/complementarity between the EU and China 's exports to the third market (in our case, Latin America), we measured the degree of substitution of Chinese and EU products for price changes. We use CEPII-BACI bilateral trade the database estimates the alternative Hicks-Allen elasticity from the hyper logarithmic cost function, namely:

$\ln Y=\ln A+\sum_{i=1}^{n} \alpha_{i} \cdot \ln X_{i}+\frac{1}{2} \sum_{i=1}^{n} \sum_{j=1}^{n} \beta_{i j} \cdot \ln X_{i} \cdot \ln X_{j}$

Where $\mathrm{Y}$ is the total import of Latin America, $\mathrm{X}_{\mathrm{i}}$ and $X_{j}$ are imports from country $i$ and country $j$. By applying Shephard's lemma, we get the following function:

$$
s_{i}=\alpha_{i}+\sum_{i=1}^{n} \beta_{i j} \cdot \ln X_{j}
$$

Where $s_{i}$ is a country's market share in the destination market. Therefore, the price elasticity is defined as follows:

$$
\eta_{i j}=\frac{\beta_{i j}}{s_{i}}+s_{j} \text { for all } i \neq j
$$

Under the assumption that the total supply function is time-varying, the above equation is close to equilibrium with the increase of the time dummy to absorb the potential time-varying total supply shock. In order to further consider the situation of supply shocks in specific industries, we have conducted empirical analysis a quantitative analysis at the industry level was also conducted.

China and the European Union 's determination to reach a free trade agreement with Latin American countries intensified their competition (Table1). The European Union first reached an agreement with Chile; subsequently, the European Union in 2013 with Central America and three Andean countries (Peru, Colombia And later Ecuador) reached two agreements. The EU has also finalized an agreement with Mexico, which is expected to be implemented soon at the time of writing. China's first agreements in Latin America were also reached with Peru and Chile In 2011, China and Costa Rica reached another bilateral trade agreement. 
Table1 Free Trade Agreement between the EU and China and Latin America

\begin{tabular}{|l|l|l|l|l|}
\hline & Partner country & $\begin{array}{l}\text { Date of entry } \\
\text { into force }\end{array}$ & End of implementation period & Type \\
\hline \multirow{5}{*}{ China } & Costa Rica & $8 / 2011$ & 2025 & $\begin{array}{l}\text { FTA \& Economic Integration } \\
\text { Agreement }\end{array}$ \\
\cline { 2 - 6 } & Chile & $8 / 2010$ & 2015, and updated in 2017 & $\begin{array}{l}\text { FTA \& Economic Integration } \\
\text { Agreement }\end{array}$ \\
\cline { 2 - 6 } & Peru & $3 / 2010$ & 2026 & $\begin{array}{l}\text { FTA \& Economic Integration } \\
\text { Agreement }\end{array}$ \\
\cline { 2 - 6 } & Mexico & $4 / 2018$ & To be implemented & EU-Mexico Global Agreement \\
\cline { 2 - 6 } & Central America & $8 / 2013$ & 2027 & $\begin{array}{l}\text { FTA \& Economic Integration } \\
\text { Agreement }\end{array}$ \\
\cline { 2 - 6 } & $\begin{array}{l}\text { Peru, Colombia, } \\
\text { Ecuador }\end{array}$ & $3 / 2013$ & 2030 & $\begin{array}{l}\text { FTA \& Economic Integration } \\
\text { Agreement }\end{array}$ \\
\cline { 2 - 5 } & & & 2013, under negotiation for \\
Eu & Update & $\begin{array}{l}\text { FTA \& Economic Integration } \\
\text { Agreement }\end{array}$ \\
\hline
\end{tabular}

Source: Bruegel

As the first attempt to quantitatively assess the proximity of EU and Chinese exports to Latin America in terms of industry distribution, we calculated a coefficient index (CI) as the arithmetic mean of two common measures in the trade literature, namely specialization Coefficient (CS) and consistency coefficient (CC) 2 (Blazquez-Lidoy et al., 2006). Figure1 and Table2 show the evolution of the index in the Latin American market from 1995 to 2016. Calculations show that China and the CI between Europe rose from 0.33 to 0.46 , which indicates that China and Europe have enough room to compete, but CI has been stagnant since the early 2010s. The country-by-country analysis further shows that
Germany, Spain, Italy and Sweden have expanded their products Coverage to compete with China in Latin America, while Portugal, France and the United Kingdom have significantly lower product coverage in the Latin American market than China.

\section{RESULTS ANALYSIS}

The estimated Hicks-Allen substitution elasticity allows us to adjust the price sensitivity among countries taking into account third-party market demand. Table 2 shows our estimation results.

Table2 Evaluation result

\begin{tabular}{|l|l|l|l|}
\hline $\begin{array}{l}\text { Elasticity of substitution in the } \\
\text { Latin America market }\end{array}$ & Europe - China & Europe - Rest of World & China - Rest of World \\
\hline $1998-2014$ & $1.24^{* *}$ & $1.01^{* *}$ & $0.96^{* *}$ \\
\hline
\end{tabular}

Source: Bruegel. Note: ${ }^{* *} p<0.05$

Very positive estimates indicate that China, the EU and the rest of the world are competing in exports to Latin America. This is a stronger proof of the earlier fashion fact that China and the EU offer similar categories of products in the Latin American market, namely Electric machinery, general machinery and road vehicles. In addition, the fact that the elasticity is greater than 1 indicates that the relative price decline of Chinese goods relative to European goods will trigger a greater reaction in the adjustment of relative demand. In other words, Latin America in terms of export revenue, China can benefit from a reduction in its relative export prices.

In addition, the absolute level of substitution elasticity between China and the EU is greater than its own substitution elasticity with the rest of the world. This means that the competition between these two groups is more intense than that with the rest of the world. Therefore, we estimate a direct conclusion is that China and the EU are competing with their exports in the Latin American market.

However, people may wonder whether this kind of export competition has become more and more fierce as China has climbed up in terms of export structure in recent years. This is our preliminary result from the evolution of the specialization coefficient between major European countries and China. The a priori hypothesis collected in Section 2 (Section 2). To test this hypothesis more accurately, we made an eight-year rolling average estimate of the substitution elasticity of EU and China's exports to Latin America. Figure5 reports the results. We found that Although China 's exports increased substantially before 2007, the level of competition between China and Europe actually declined during the same period as of 2007. This result is that after China 's accession to the World Trade Organization (WTO), the average quality of Chinese exports is lower than that of the EU. The views of export products are consistent. However, since then, with the rapid recovery of substitution elasticity, this trend has reversed.

Since then, as China's exports have expanded to higher value-added industries, the previous situation has undergone substantial changes.

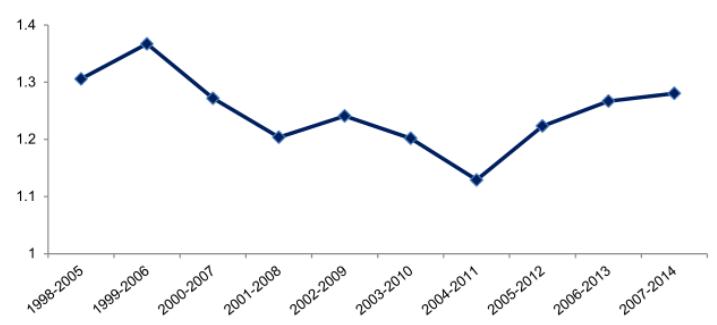

Figure5 Evolution of the average substitution elasticity of Europe and China in the Latin American market 
A further breakdown of selected countries shows that China 's most obvious competitor in 2005 was Spain, because its substitution elasticity relative to China 's exports was the most flexible (Figure6). Today, the United Kingdom and France are actually the most obvious in China in Latin America. The pattern of this change seems to be consistent with the corresponding changes in the market share of the two countries: the UK's share of Latin American imports has fallen sharply compared to Spain (only a decrease of $16 \%$ over the same period) (from 2012 to 2016) 31\%).

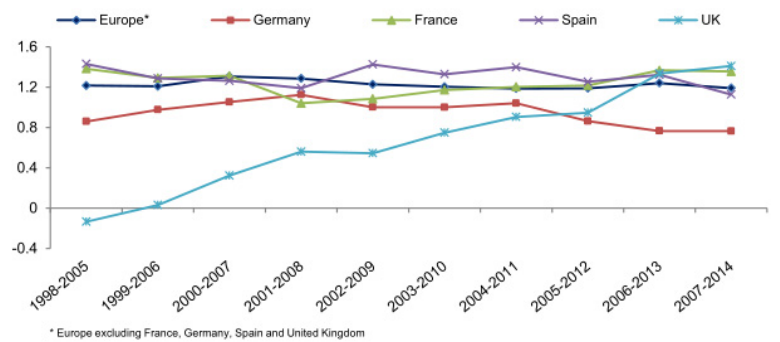

Figure6 Average elasticity over time between China and some EU countries

Turning now to the potential differences between products, we estimate the sector-level resilience of EU and Chinese exports to Latin America. To this end, we follow the SITC Rev. 4 classification, and the 10 largest sectors in each country are shown in Figures5 and 5. As shown in Figure 6, the estimated elasticity allows us to divide all sectors into two groups: the 10 most complementary sectors (ie the least elastic sectors) and the 10 most competitive sectors. Figures 7 and 8 report this two categories. The results show that the EU's high value-added industries, such as motors and office machinery, face fierce competition from China 's exports. This is consistent with China 's upward climb in export structure. Our results are also consistent with Hausmann et al. The results of (2007) are consistent, and they find that China's export bundling increasingly overlaps with the world's most developed economies.

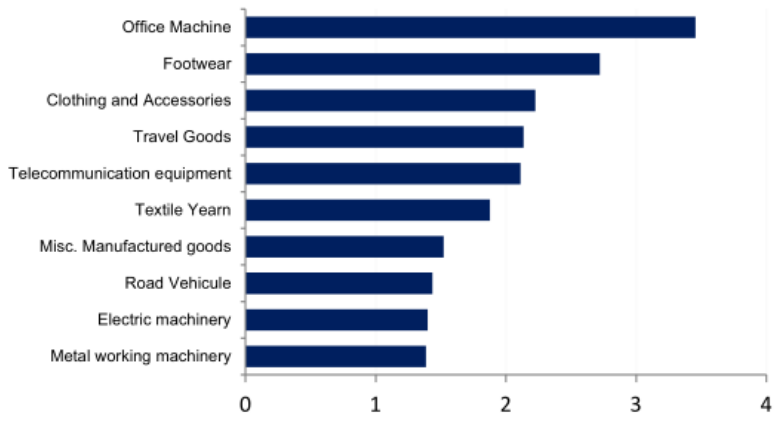

Figure7 CEIBS has greater cross-industry flexibility in Latin America

However, of these highly alternative products, only a few are exported to Latin America by the EU and China with a sufficiently large market share at the same time. Among the products with the largest exports to Latin America (top 10) in Europe, only road vehicles and electric machinery. It has a high substitution elasticity with similar Chinese exports. Therefore, these two sectors are systematically related to the future of EU exports to Latin America. Therefore, a warning flag can be raised to show that high-end products exported by the EU are facing more and more. Difficult competitive environment. More specifically, if China continues to climb the ladder, as the "EU Chamber of Commerce in China (2017)" envisions, the EU may find it more difficult to compete with China in third-party markets Competition, even in capital-intensive industries, is already the case with electric machinery and road vehicles, at least in Latin America.

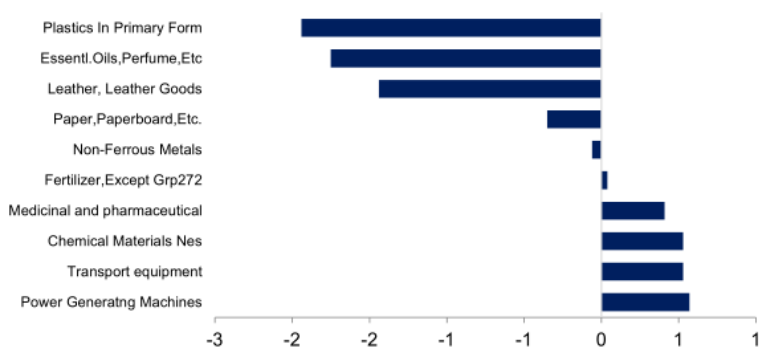

Figure8 Central Europe has low flexibility in various industries in Latin America

\section{CONCLUSION}

In this article, we first record the seemingly puzzling pattern of production and export structure adjustment based on comprehensive data at the level of Chinese companies: from 1999 to 2007, manufacturing production as a whole became more capital-intensive, while exports did not ; Labor-intensive industries'export participation rises, while capital-intensive industries' export participation declines. It runs counter to our understanding of Ho 's 30 Lebzinski's theorems. To explain these findings, we refer to the Melitz type. The heterogeneous enterprise model is embedded in the Ricardo and Heckscher-Olin trade theory with continuous industries.

We conducted a structural estimation of the model and found that from 1999 to 2007, China's capital was relatively abundant, and technological progress was significant, which was beneficial to labor-intensive industries. Trade liberalization reduced variable trade costs by about a quarter. In fact simulation, we found that the adjustment of production mode is mainly driven by the change of endowment, and the change of export participation is mainly driven by the change of technology. Using the estimated model, we find that export choices broadly shape Ricardo's comparative advantage However, the contribution rate to productivity growth after overtime is only about $2.1 \%$. Finally, the growth of China's output and welfare is mainly driven by technological changes, not endowment and trade liberalization.

To assess the competition between China and the EU in the Latin American market, we empirically estimate the substitution elasticity of Europe and China in the Latin American market, that is, their response to Latin 
American exports to changes in relative export prices. Our results show that China and the EU are in Latin America. The level of competition in the Americas seems to change over time. Before 2007, there was less competition between China and the European Union, which reflected to a certain extent the fact that China mainly exports low-quality products. The EU's goal is a higher-end market. However, as China gradually climbs up the value chain, it also begins to produce more high-quality products, resulting in a higher substitution elasticity relative to the EU. In fact, China and the EU Competition on some high-end products has become more intense, especially electrical machinery and road vehicles. This discovery should sound the alarm for Europe seeking to remain competitive at the global level.

\section{REFERENCES}

1. Autor, D., D. David and G. Hanson (2013) 'The China syndrome: Local labor market effects of import competition in the United States', American Economic Review 103(6): 2121-68

2. Blazquez-Lidoy, J., J. Rodriguez and J. Santiso (2006) 'Angel or Devil? China's trade impact on Latin American emerging markets', OECD Development Center working paper No.252

3. Bloom, N., M. Draca and J. Reenen (2016) 'Trade induced technical change? The impact of Chinese imports on innovation, IT and productivity', The Review of Economic Studies 83(1): 87-117

4. European Union Chamber of Commerce in China (2017) China Manufacturing 2025: Putting Industrial Policy Ahead of Market Forces.

5. Zhu Guoli. Ways for China to Create Competitive Advantage in International Trade [J]. economic research guide, 2020(06): 148-150.

6. Li Yuxin, Yoko. Study on Trade Competitiveness and Complementarity between China and Eurasian Economic Union $[\mathrm{J}]$. Commercial Economic Research, 2019(24): 135-139.

7. Guo Huijie. Understanding Trade Protection and Competitive Advantage from Comparative Advantage [J]. Economist, 2019(11): 21-22.

8. Wang Yupeng. Policy Risks and Countermeasures of Chinese Enterprises to European Trade and Investment [J]. International Trade, 2019(04): 60-67.

9. Mei Xinyu. European Trade Protection Difficult to Block China's Economic Growth [N]. People's Daily Overseas Edition, 2016-05-18(001).

10. Li Hao. Study on Economic and Trade Relations between China and European Union [D]. Inner Mongolia University, 2012. 